\title{
Sightings of Peregrine Falcons (Falco peregrinus) at Presumed Nest Sites in Eastern Hudson Bay, Summer 1985
}

D.M. ALBRIGHT ${ }^{1}$ and D.W. DOIDGE ${ }^{2}$

(Received 3 January 1991; accepted in revised form 2 December 1991)

\begin{abstract}
Eastern Hudson Bay breeding distribution of the peregrine falcon is poorly documented. We report the observation of immature falcons and behaviour of adult birds that strongly suggest the existence of a breeding population of peregrine falcons on islands near the Nastapoka River.

Key words: nesting, peregrine falcon, Falco peregrinus, Nastapoka Islands
\end{abstract}

RÉSUMÉ. Il existe peu de descriptions de la distribution du faucon pèlerin nicheur dans l'est de la baie d'Hudson. On rapporte des observations de faucons immatures et des comportements d'oiseaux adultes qui tendent à prouver l'existence d'une population reproductrice de faucons pèlerins sur des îles situées près de la rivière Nastapoka.

Mots clés: nidification, faucon pèlerin, Falco peregrinus, îles Nastapoka

Traduit pour le journal par Nésida Loyer.

Fyfe (1969) classified the Hudson Bay Arc (Cape Dufferin to Poste-de-la-Baleine; Fig. 1) as optimum nesting habitat for peregrine falcons (Falco peregrinus Tunstall), yet there are few reports of observations from the area. In 1915 O.J: Murie

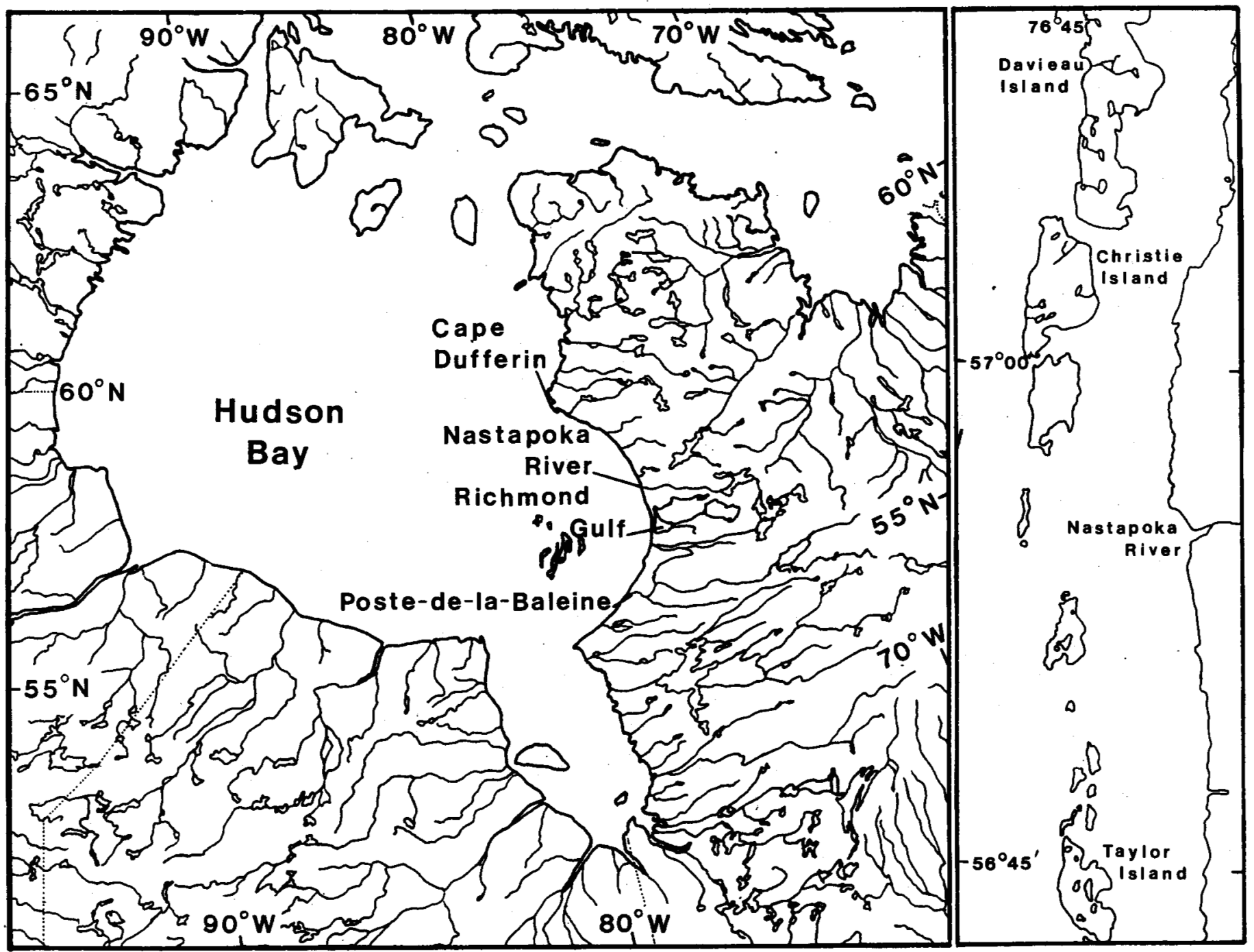

FIG. 1. Location of features mentioned in text. Detail map shows islands of the Nastapoka group, near the mouth of the Nastapoka River.

\footnotetext{
${ }^{1}$ Department of Zoology, University of Alberta, Edmonton, Alberta, Canada T6G 2E9; present address: Box 3, Site 6, Hythe, Alberta, Canada T0H 2C0

${ }^{2}$ Makivik Research Centre, P.O. Box 179, Kuujjuaq, Quebec, Canada J0M 1C0

(C)The Arctic Institute of North America
} 
(cited in Todd, 1963) recorded four sightings of falcons on the Hopewell Islands (parallel to the coast south of Cape Dufferin for $80 \mathrm{~km}$ ) and Nastapoka Islands (parallel to the coast for $160 \mathrm{~km}$ north of Richmond Gulf). Manning (1946) reported a breeding pair on Christie Island (Fig. 1 detail) and Savile (1950) saw a falcon on two separate days in early autumn near Poste-de-la-Baleine. However, Bird and Bider (in Fyfe et al., 1976) were unable to locate any birds between Poste-de-laBaleine and Richmond Gulf but did note unsubstantiated reports of a good breeding population on the islands along the coast in the 1940s and 1950s. The late Daniel Weetalutuk of Inukjuak, using an ultralight aircraft, found three active nests on the Nastapoka Islands (D.M. Bird, pers. comm. 1986).

We spent the summer of 1985 encamped at the mouth of the Nastapoka River $\left(56^{\circ} 55^{\prime} \mathrm{N}, 76^{\circ} 33^{\prime} \mathrm{W}\right)$. As part of our work on marine mammals, we travelled by freighter canoe in the vicinity of the Nastapoka Islands. We usually travelled on the east side of the islands and did not intentionally flush birds or land on the islands to pinpoint nests. Slaty upperparts, dark malar bars, and pale throats characterize this easily identified species.

The Nastapoka Islands rise gradually out of the water on their western side but present steep, often broken cliffs on their eastern aspect. These rocky cliffs, with numerous ledges and cavities and close to an abundance of seabirds, make the area attractive to peregrine falcons (Fyfe, 1969). Although we did not attempt to locate the actual nests, the birds' behaviour at three sites (Table 1) strongly indicated active nesting in the area. The "cack-cack-cack" call given by the falcons is indicative of peregrines defending a nest site (Ratcliffe, 1980). The appearance of a second bird at the Davieau Island site suggests hatching had occurred. During incubation the female seldom flushes, but after hatching, she becomes more aggressive and both birds are frequently seen demonstrating (Ratcliffe, 1980). The appearance of immature birds at our camp (Table 1) sug-

TABLE 1. Sightings of peregrine falcons in eastern Hudson Bay, summer 1985

\begin{tabular}{lccl}
\hline \hline Location & Date & $\begin{array}{c}\text { Number } \\
\text { of birds }\end{array}$ & Comments \\
\hline $\begin{array}{l}\text { Taylor Island } \\
\left(56^{\circ} 43^{\prime} \mathrm{N}, 76^{\circ} 37^{\prime} \mathrm{W}\right)\end{array}$ & $17 / 07$ & 1 & Cacking \\
$\begin{array}{l}\text { Christie Island } \\
\left(57^{\circ} 03^{\prime} \mathrm{N}, 76^{\circ} 40^{\prime} \mathrm{W}\right)\end{array}$ & $19 / 07$ & 1 & Cacking \\
$\begin{array}{l}\text { Davieau Island } \\
\left(57^{\circ} 08^{\prime} \mathrm{N}, 76^{\circ} 38^{\prime} \mathrm{W}\right)\end{array}$ & $30 / 07$ & 1 & Cacking \\
$\begin{array}{l}\text { Nastapoka River estuary } \\
\left(56^{\circ} 55^{\prime} \mathrm{N}, 76^{\circ} 33^{\prime} \mathrm{W}\right)\end{array}$ & $22 / 08$ & 2 & Cacking \\
\hline \hline
\end{tabular}

gests nesting in the area, although they may have been migrants from farther north.

The bird on Christie Island was seen only once, despite several trips past the site. However, we do not believe it was the same bird seen on Davieau Island. The birds at both sites flew over us cacking - normal behaviour of a falcon near its nest. The distance between the two sites is $8 \mathrm{~km}$, which is greater than all but one of the average nearest neighbour distances given by Ratcliffe (1980:Table 20). The behaviour exhibited at each location and the distance separating them suggest they are discrete sites.

Traditional use of certain cliffs by peregrines has been proposed (Hickey and Anderson, 1969). Unfortunately neither Murie (Todd, 1963) nor Manning (1946) is specific about the location of nests on Christie Island. We are thus unable to comment on traditional use of this site.

The Nastapoka River is depicted by Murphy (1990:Fig. 1) as near the dividing line between the F.p. anatum and F.p. tundrius subspecies. This would make it another area useful to test the hypothesis of a latitudinal cline of morphological variation for peregrine falcons (Court et al., 1988).

\section{ACKNOWLEDGEMENTS}

DMA was supported by a Natural Sciences and Engineering Research Council Undergraduate Summer Award. DWD was employed by the Department of Fisheries and Oceans Challenge 85 program. The Arctic Biological Station, D.F.O., and the World Wildlife Fund "Whales Beneath the Ice" program provided logistic support. We thank Drs. T.G. Smith, D.M. Bird, J.-F. Giroux, E. Kuyt and two anonymous referees for editorial comments.

\section{REFERENCES}

COURT, G.S., GATES, C.C., and BOAG, D.A. 1988. Natural history of the peregrine falcon in the Keewatin district of the Northwest Territories. Arctic 41:17-30.

FYFE, R. 1969. The peregrine falcon in northern Canada. In: Hickey, J.J., ed. Peregrine falcon populations: Their biology and decline. Madison: University of Wisconsin Press. 101-114.

FYFE, R.W., TEMPLE, S.A., and CADE, T.J. 1976. The 1975 North American peregrine falcon survey. Canadian Field-Naturalist 90:228-273.

HICKEY, J.J., and ANDERSON, D.W. 1969. The peregrine falcon: Life history and population literature. In: Hickey, J.J., ed. Peregrine falcon populations: Their biology and decline. Madison: University of Wisconsin Press. 3-42.

MANNING, T.H. 1946. Bird and mammal notes from the east side of Hudson Bay. Canadian Field-Naturalist 60:71-85.

MURPHY, J.E. 1990. The 1985-1986 Canadian peregrine falcon, Falco peregrinus, survey. Canadian Field-Naturalist 104:182-192.

RATCLIFFE, D. 1980. The peregrine falcon. Vermillion, South Dakota: Buteo Books.

SAVILE, D.B.O. 1950. Bird notes from Great Whale River, Que. Canadian Field-Naturalist 64:95-99.

TODD, W.E.C. 1963. Birds of the Labrador Peninsula and adjacent areas. Toronto: University of Toronto Press. 